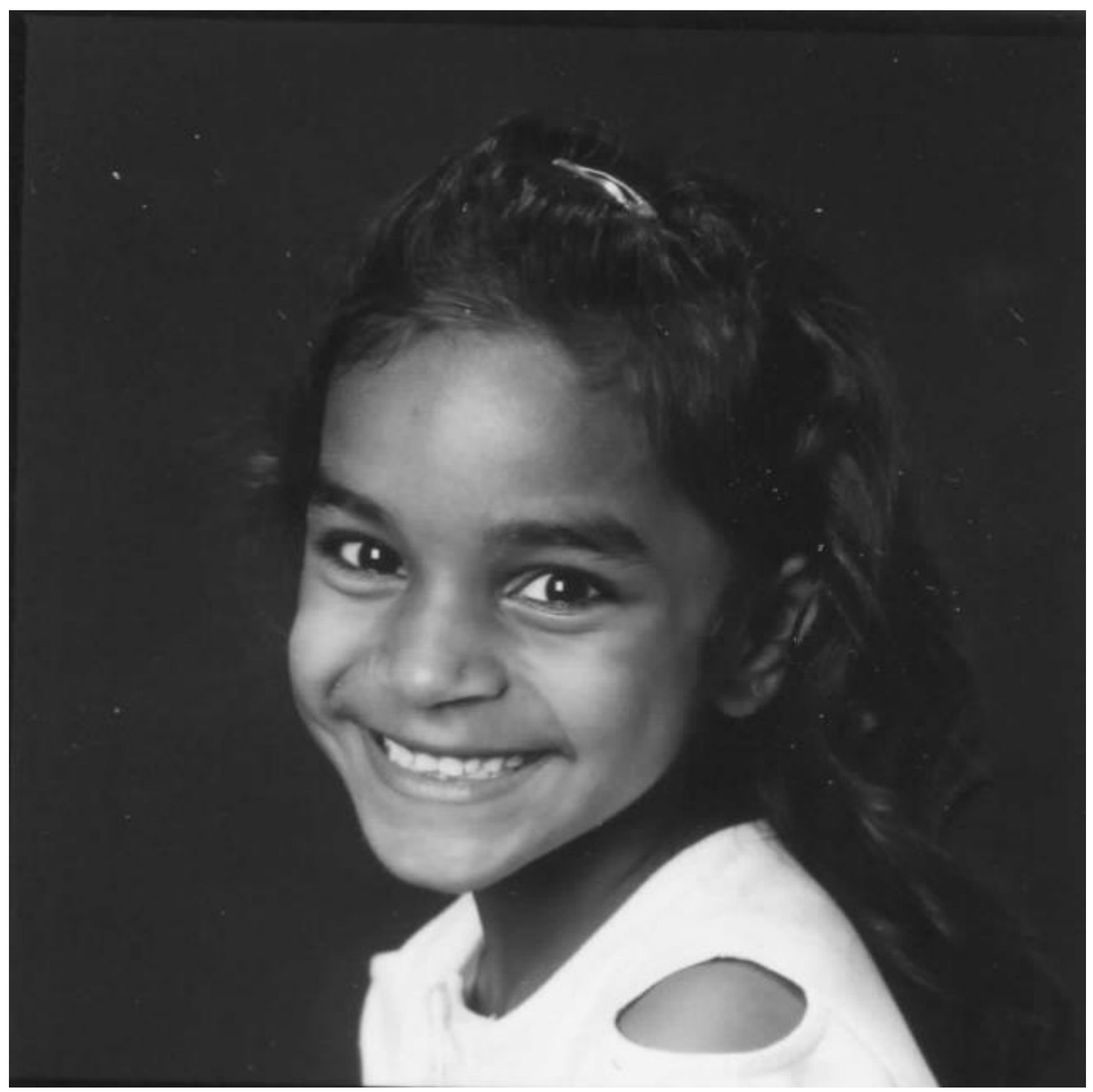

\title{
Rose's Smile
}

(Photograph from Maria Wallis' personal collection)

Cultural and Pedagogical Inquiry, Fall 2016, 8(2), p. 84

ISSN 1916-3460 @ 2016 University of Alberta

http://ejournals.library.ualberta.ca/index.php/cpi/index 